Article

\title{
Prismatic to Asbestiform Offretite from Northern Italy: Occurrence, Morphology and Crystal-Chemistry of a New Potentially Hazardous Zeolite
}

\author{
Michele Mattioli ${ }^{1, *(1)}$, Matteo Giordani ${ }^{1}{ }^{(0)}$, Pierluca Arcangeli ${ }^{1}$, Laura Valentini ${ }^{2}$, \\ Matteo Boscardin ${ }^{3}$, Alessandro Pacella ${ }^{4}$ and Paolo Ballirano ${ }^{4,5}$ (iD) \\ 1 Department of Pure and Applied Sciences, University of Urbino Carlo Bo, Scientific Campus E. Mattei, \\ via Cà le Suore 2, 61029 Urbino, Italy; matteo.giordani@uniurb.it (M.G.); pierluca.bibo@hotmail.it (P.A.) \\ 2 Department of Biomolecular Sciences, University of Urbino Carlo Bo, Scientific Campus E. Mattei, \\ via Cà le Suore 2, 61029 Urbino, Italy; laura.valentini@uniurb.it \\ 3 Museum of Archeological and Natural Sciences “G. Zannato", Montecchio Maggiore, 36075 Veneto, Italy; \\ m.boscardin@tin.it \\ 4 Department of Earth Sciences, Sapienza University of Rome, Piazzale Aldo Moro 5, 00185 Roma, Italy; \\ alessandro.pacella@uniroma1.it (A.P.); paolo.ballirano@uniroma1.it (P.B.) \\ 5 Rectorial Laboratory Fibres and Inorganic Particulate, Sapienza University of Rome, Piazzale Aldo Moro 5, \\ 00185 Roma, Italy \\ * Correspondence: michele.mattioli@uniurb.it; Tel.: +39-0722-304312
}

Received: 21 January 2018; Accepted: 12 February 2018; Published: 14 February 2018

\begin{abstract}
A multi-methodological approach, based upon field investigation, morphological characterization, chemical analysis and structure refinement was applied to different samples of fibrous offretite, a new potentially hazardous zeolite recently discovered in northern Italy. Their morphology ranges from stocky-prismatic to asbestiform. All the investigated fibers may be considered as "inhalable", and they are well within the range of the "more carcinogenic fibers" regarding diameter. As regards the length, the main mode observed in the asbestiform samples is $20-25 \mu \mathrm{m}$, and $\sim 93 \%$ of the measured fibers are $>5 \mu \mathrm{m}$ and may be significantly associated with carcinogenesis also in terms of lengths. The chemical-structural features of the investigated fibers are comparable: the extra-framework cations $\mathrm{K}^{+}, \mathrm{Mg}^{2+}$ and $\mathrm{Ca}^{2+}$ are present in all samples in similar proportions, and refined cell parameters are similar among the samples. Offretite occurs in $60 \%$ of the investigated sites, with an estimated amount up to $75 \mathrm{vol} \%$ of the associated minerals. The presence of this mineral could be of concern for risk to human health, especially if one considers the vast number of quarries and mining-related activities that are operating in the zeolite host rocks.
\end{abstract}

Keywords: zeolites; offretite; fibers; carcinogenic; human health; Italy

\section{Introduction}

In recent years, a subject of great interest has been that of inhalable mineral fibers and their potential health effects [1,2]. One of the most important factors for defining the hazardousness of mineral fibers is their size or their tendency to split into smaller fibrils that are easily inhalable [3-7]. The biopersistence of fibers, defined as their ability to persist in the human body to chemical, physical, and other physiological clearance mechanisms, is another important factor for inducing toxicity and carcinogenicity [8-10]. Accordingly, it has been shown that an inhalable fiber might be carcinogenic if it is sufficiently durable to remain chemically and physically unaltered within the lung tissue [11]. In addition to biopersistence, the presence and structural coordination of $\mathrm{Fe}$ in the mineral fibers were proposed to play a key role in the carcinogenic mechanisms [12-14]. Other properties of fibers, including trace elements content, specific surface area, interacting capability, 
zeta potential, and microtopography might also act as important co-factors in fiber-induced toxicity and carcinogenicity [15-18].

There are six fibrous minerals with asbestiform habit currently regulated by the normative as asbestos [19,20]: chrysotile, amosite, crocidolite, tremolite, actinolite, anthophyllite. Recently, epidemiological studies revealed several cases of environmental contamination of other, non-regulated fibrous minerals. They are (1) amphiboles (winchite, richterite, fluoro-edenite [21,22]); (2) mineral species with a chemical composition similar to asbestos (fibrous antigorite, balangeroite [23,24]); and (3) further fibrous minerals (fibrous zeolites, talc, clay minerals as sepiolite and palygorskite [25-29]). Among fibrous zeolites, erionite captured the interest of both the public opinion and the scientific community since it has been responsible for an epidemic of mesothelioma in some villages of Cappadocia region (Turkey), where houses were built with erionite-bearing rocks. In these villages, up to $50 \%$ of the yearly deaths were due to mesothelioma, the highest rates of cancer-related to environmental exposure to fibrous minerals ever reported [30-32]. Toxicological studies have shown that fibrous erionite is significantly more carcinogenic than chrysotile and crocidolite [33-37]. Accordingly, erionite has been classified as a Group 1, known Human-Carcinogen, by the International Agency for Research on Cancer [38,39]. Recently, many concerns regarding the potential risks for environmental and occupational exposures to erionite have developed in the western USA [40-42], Mexico [43,44], Iran [45] and Italy [46,47]. It must be pointed out that a recent investigation on the surface properties of fibrous zeolites [18] showed a significant surface reactivity of offretite, a zeolite closely related both structurally and chemically to erionite. Moreover, recent works [48,49] highlighted that fibrous offretite could cause some toxic effects on human health. On this basis, the acquisition of further knowledge on fibrous offretite is of paramount importance to predict its potential toxicity and to prevent other occurrences of unexpected pathologies.

Offretite crystallizes in the hexagonal system, space group P6m2, cell parameters $a=13.27-13.32 \AA$, $c=7.56-7.61 \AA$, average chemical formula $\mathrm{KCaMg}\left(\mathrm{Al}_{5} \mathrm{Si}_{13} \mathrm{O}_{36}\right) \cdot 16 \mathrm{H}_{2} \mathrm{O}$. It forms simple hexagonal prisms and needles associated in both parallel and radiating aggregates [50-52], but it is also known to crystallize with fibrous habit [53]. Offretite typically occurs as fine microscopic crystals of hydrothermal origin clustered in vugs and veins of basic volcanic rocks, but it has also been found in cavities of arenaceous metasiltites or cornubianites [53]. Frequently, it is associated with many other zeolites such as mazzite, chabazite, levyne, erionite, phillipsite, faujasite, and epitaxial overgrowth on levyne and chabazite $[52,53]$. Moreover, given the strong correlation between their respective structures and chemistry, the structural epitaxy of offretite and erionite is common [54]. Thus, the distinction between these two species is often very difficult even by X-ray powder diffraction data [51].

The first occurrence of offretite in Italy was reported in a cornubianite rock from Passo Forcel Rosso, Adamello, as milky-white fibers in epitaxy with chabazite [53]. From another locality of this area and in the same host-rock, offretite with a barrel-like habit has been found [55]. Other occurrences of offretite in Italy have been reported in the vugs of basaltic rocks outcropping in several localities in the Vicenza and Verona provinces (Fittà, Cerealto, Alvese, Montorso Vicentino and Passo Roccolo). The corresponding offretite crystals show habits ranging from the barrel- to needle-like prisms, frequently associated as parallel aggregates or grouped in sub-spherical forms [51,56-59]. However, despite these studies, many mineralogical and toxicological aspects of Italian offretite remain unknown.

In this study, we present a detailed morphological, chemical and structural characterization of different samples of offretite recently discovered in northern Italy, some of which show an asbestiform habit. Scanning Electron Microscopy with Energy Dispersive Spectroscopy (SEM-EDS) and X-ray Powder Diffraction (XRPD) data were combined and integrated, to characterize from the morphological, crystal chemical and structural point of view this mineral, with particular attention to the fibers of inhalable size, which could be generated from these samples. 


\section{Materials and Methods}

Three different samples of offretite (named FF102, AD13, MB2287) were investigated in this study (Table 1). They were selected over a sample set of over 100 new specimens from the investigated outcrops (Table 1), according to the three main morphologic types recognized in northern Italy: stocky-prismatic with a solid appearance (FF102), prismatic to acicular with rigid mechanical behavior (AD13), and asbestiform with rigid to flexible behavior (MB2287).

Table 1. Synoptic table showing locations, geographic coordinates, mineral assemblages and offretite amounts of the investigated outcrops from northern Italy. CHA—chabasite; OFF-offretite; ERI—erionite; CM—clay minerals; PHI/HAR—phillipsite/harmotome; NAT—natrolite; ANA—analcime; YUG-yugawaralite; GYR—gyrolite; PRE-prehnite; GIS—gismondine.

\begin{tabular}{cccccc}
\hline Locality & Latitude & Longitude & $\begin{array}{c}\text { Altitude } \\
\text { (m a.s.1.) }\end{array}$ & Mineral Association & $\begin{array}{c}\text { Offretite } \\
\text { (vol \%) }\end{array}$ \\
\hline Marcantoni & 45.360653 & 11.174968 & 555 & CHA + OFF + ERI + CM & 60 \\
Nogare (FF102) & 45.362673 & 11.180461 & 401 & OFF + ERI + CM & 75 \\
Battistini & 45.361506 & 11.175586 & 474 & PHI/HAR + CHA + ERI + OFF + CM & 35 \\
Mattiazzi & 45.361784 & 11.180102 & 468 & OFF + ERI+ CM & 70 \\
\hline Foscarino Mt. & 45.439427 & 11.258779 & 296 & PHI/HAR + ERI + OFF + CM & 30 \\
Colombara & 45.426723 & 11.277245 & 140 & PHI/HAR + CHA + OFF + ERI + CM & 40 \\
Fittà (AD13) & 45.453548 & 11.253994 & 281 & PHI/HAR + OFF +ERI + CM & 70 \\
Calvarina Mt. & 45.490955 & 11.269361 & 280 & NAT + ANA + ERI + OFF + CM & 15 \\
Chiereghini V. & 45.549751 & 11.219361 & 285 & PHI/HAR + NAT + OFF + CM & - \\
S.Giovanni Il. & 45.521057 & 11.236276 & 194 & ANA + ERI + OFF + PHI/HAR + CM & 30 \\
Beltrami & 45.525522 & 11.229305 & 253 & PHI/HAR + CHA + OFF + CM & 20 \\
Bagattei & 45.551624 & 11.218733 & 329 & PHI/HAR + ERI + OFF + YUG + CM & 35 \\
Soave & 45.419776 & 11.247955 & 50 & OFF + ERI + GYR + PRE + CM & 75 \\
Roncà & 45.480646 & 11.288877 & 80 & ANA + OFF + PHI/HAR + CM & 55 \\
Prun & 45.577982 & 10.951481 & 541 & CHA + OFF + ERI + CM & 60 \\
S. Cristina & 45.581039 & 10.940663 & 683 & PHI/HAR + CHA + ERI + OFF + CM & 10 \\
\hline Saviore (MB2287) & 46.025012 & 10.255729 & 1845 & CHA + OFF + CM & 65 \\
La Trabersera & 46.024379 & 10.271761 & 1825 & CHA + OFF + PHI/HAR + CM & 45 \\
Lago d'Arno E & 46.023939 & 10.273229 & 1827 & CHA + OFF + GIS + CM & 40 \\
\hline
\end{tabular}

The samples FF102 and AD13 originated from Nogare (VI) and Fittà (VR), respectively, in the Lessini Mountains (northern Italy), where a thick sequence of lava flows of the Veneto Volcanic Province extensively crops out $[60,61]$. These lavas range from poorly to highly vesiculated and scoriaceous basalts and basanites. Their vesicles are often filled with secondary minerals, which are dominated by zeolites of hydrothermal origin (mainly analcime, chabazite, phillipsite-harmotome, gmelinite, erionite, and offretite). Based on the different secondary mineral assemblages, multi-stage alteration processes have been described in the Lessini basalts [56].

The sample MB2287 originated from Saviore dell'Adamello (BS) and had been found in cavities of an arenaceous metasiltite, metasomatised by the Adamello intrusion. This rock, which is a fine-grained, black cornubianite belonging to the Servino Formation, is characterized by the presence of large druses filled by secondary minerals such as zeolites (chabazite, gismondine, offretite, mesolite, phillipsite) and other phases (calcite, pyrite, actinolite, muscovite). The association offretite-chabazite is already known in this area [53,55]; however, the morphology of offretite crystals in our sample is notably different concerning that described in the literature, and this is the first time that asbestiform offretite is found in northern Italy.

Morphological observations were performed at the University of Urbino Carlo Bo using an Environmental Scanning Electron Microscope (ESEM) FEI Quanta 200 FEG (FEI, Hillsboro, OR, USA), equipped with an energy-dispersive X-ray spectrometer (EDS) for microchemical analyses. Operating conditions were $30 \mathrm{kV}$ accelerating voltage, $10 \mathrm{~mm}$ working distance, $0^{\circ}$ tilt angle, and variable beam diameter. The ESEM was utilized in low vacuum mode, with a specimen chamber pressure set from 0.80 to 0.90 mbar. The images were obtained using a back-scattered electron detector. For the sample MB2287, given the very small size fibers and asbestiform habit, morphometric data were collected by accurate size measurements (length and diameter) of the offretite fibers visible in several ESEM images. 
SEM-EDS analyses were performed on free surfaces of selected crystals and renormalized using a theoretical water content of $19.34 \mathrm{wt} \%$, corresponding to the grand mean values of offretite samples previously analyzed; the final crystal-chemical formula was calculated by $18(\mathrm{Si}+\mathrm{Al})$ atoms per formula unit (apfu). As previously suggested [62,63], to minimize the alkali metal migration, chemical data were acquired using a low counting time and a raster scan mode to reduce the temperature increase. The reliability of the chemical analysis used to classify the offretite samples was evaluated by using the charge balance error formula (E\% within $\pm 10 \%$; [51,64]), the Mg-content [65] and the K-content tests, similarly to erionite [66].

XRPD data were collected for all the studied samples. Crystals were selected under a binocular microscope. They were reduced in powder using an agate mortar and loaded into $0.5 \mathrm{~mm}$ diameter $\mathrm{SiO}_{2}$-glass capillaries. XRPD data were collected in transmission mode using a D8 Advance diffractometer (Bruker AXS, Karlsruhe, Germany) operating in $\theta / \theta$ geometry. The instrument is fitted with focusing Göbel mirrors on the incident beam, Soller slits on both incident and (radial) diffracted beams, and a PSD VÅNTEC-1 detector. The Rietveld method was used to determine the cell parameters of offretite. However, in the case of sample AD13 that was found to consist of pure offretite, a full structure refinement was carried out using TOPAS v.4.2 [67] and modeling the peak shape by FPA (Fundamental Parameters Approach). Starting structural model of offretite was taken from [68]. We adopted the same Rietveld refinement procedure used by the present research group in several structure refinements of erionite fibers $[12,69]$. Owing to the occurrence of correlations between site occupancy factors and displacement parameters, the latter were constrained as follows: $\mathrm{B}_{\mathrm{Si} 1}=\mathrm{B}_{\mathrm{Si} 2} ; \mathrm{B}_{\mathrm{O} 1}=\mathrm{B}_{\mathrm{O} 2}=\mathrm{B}_{\mathrm{O} 3}=\mathrm{B}_{\mathrm{O} 4}=\mathrm{B}_{\mathrm{O} 5}=\mathrm{B}_{\mathrm{O} 6} ; \mathrm{B}_{\mathrm{K} 1}=\mathrm{B}_{\mathrm{Mg} 1} ; \mathrm{B}_{\mathrm{Ca} 1}=\mathrm{B}_{\mathrm{Ca} 2}$; $\mathrm{B}_{\mathrm{OW} 7}=\mathrm{B}_{\mathrm{OW} 8}=\mathrm{B}_{\mathrm{OW} 9}=\mathrm{B}_{\mathrm{OW} 10}=\mathrm{B}_{\mathrm{OW} 11}=\mathrm{B}_{\mathrm{OW} 12}$. Absorption correction was performed following the formalism of [70], and the occurrence of preferred orientation was modeled by spherical harmonics selecting the number of terms to be used according to the procedure devised by [71]. Moreover, the refinement was performed using the ellipsoid-model of [72] describing the diffraction-vector dependent broadening of diffraction maxima. Full structural data of the samples were submitted as CIF file in the Supplementary Material.

\section{Results}

\subsection{Morphology}

The FF102 sample contains stocky-prismatic crystals of offretite showing well-shaped hexagonal or pseudo-hexagonal habits with diameters of $\sim 50 \mu \mathrm{m}$ and lengths up to $200 \mu \mathrm{m}$ (Figure 1a,b). They occur as irregular aggregates of several individual crystals, but isolated single prisms are also observed. In some cases, the crystals termination shows smaller size and irregular morphology due to the presence of a network of fractures. The crystals of this sample have a compact aspect and a rigid behavior and do not originate any fibrous element.

In the AD13 sample, offretite occurs as very elongated, hexagonal (or pseudo-hexagonal) prismatic crystals of solid appearance, with size $\sim 50 \mu \mathrm{m}$ concerning diameter, and up to $500 \mu \mathrm{m}$ regarding length (Figure 1c,d). Furthermore, in the same sample, acicular to fibrous offretite crystals with diameters $<1 \mu \mathrm{m}$ and lengths up to $500 \mu \mathrm{m}$ are also present, sometimes grouped in radiating bundles of larger size. These fibrous crystals show a rigid behavior, even if some fibers are curved and seem to display flexibility. In any case, both single prismatic and acicular crystals present a well-shaped morphology, and no fractures are recognizable.

In the MB2287 sample, offretite is found under the form of very thin fibers densely associated in parallel aggregates, which grow as a coating on the main surfaces of platy, rhombohedral chabazite crystals, creating a sandwich-like morphology (Figure 1e). In this sample, offretite is characterized by an extremely fibrous habit, consisting of fibers and fibrils with a diameter ranging from $<<1 \mu \mathrm{m}$ to about $4 \mu \mathrm{m}$, and variable lengths (generally about $20 \mu \mathrm{m}$; Figure 1f). Accordingly, it might be described 
as having an asbestiform habit. The coatings are always characterized by a great tendency to separate in fibers and fibrils of the thinner section, with rigid to flexible behavior.
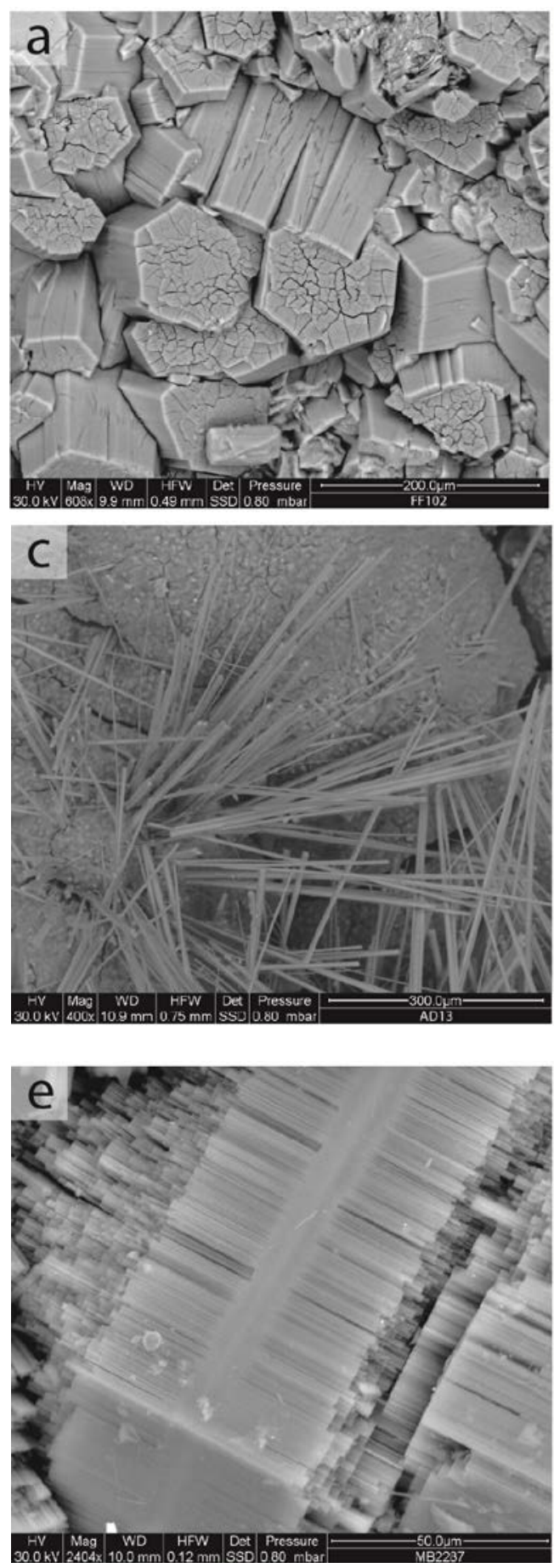
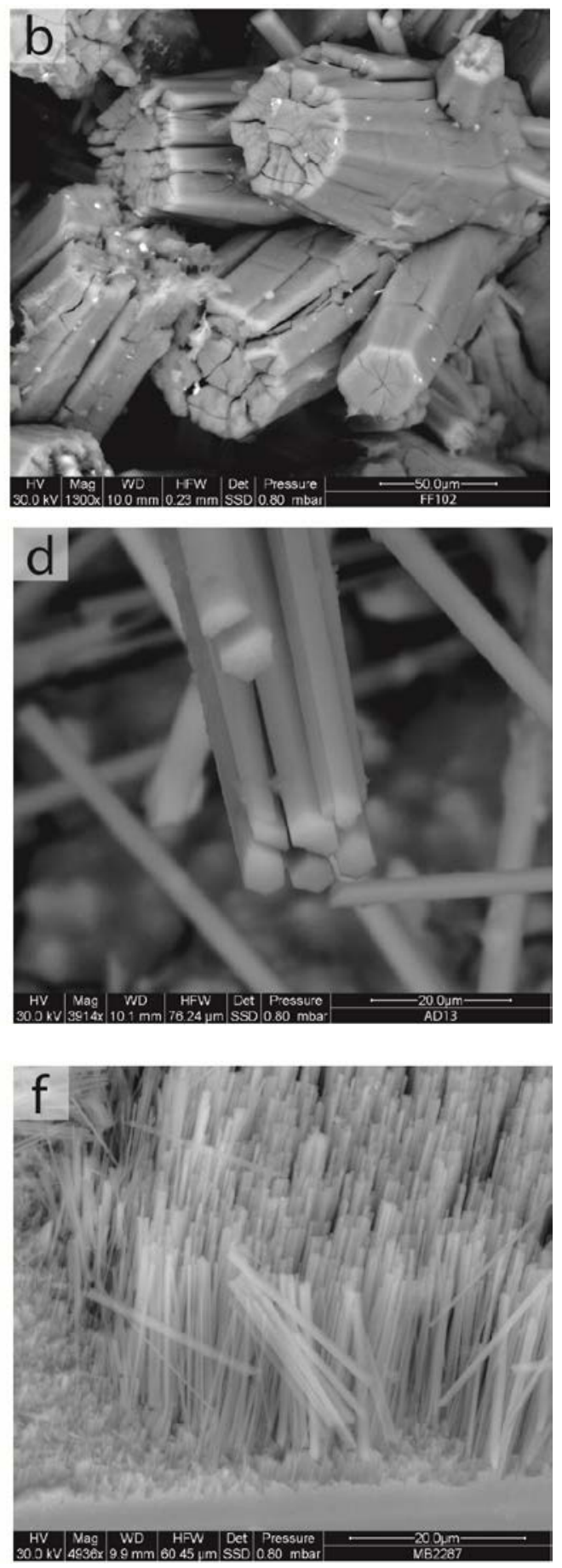

Figure 1. Representative SEM images of the studied samples. (a) Stocky-prismatic crystals of offretite with hexagonal section (FF102); (b) Radial aggregates of offretite prisms, characterized by evident fractures (FF102); (c) Very elongated, acicular to fibrous offretite crystals grouped in radial aggregates with rigid to flexible behavior (AD13); (d) Particular of the previous sample showing the thin diameter of hexagonal offretite fibrils (AD13); (e) The offretite-chabazite-offretite sequence is forming a sandwich-like morphology (MB2287); (f) Details of the parallel growth of the asbestiform offretite consisting of rigid to flexible thin fibers and fibrils (MB2287). 
Considering the asbestiform nature of the MB2287 sample, morphometric analyses were performed on about 100 ESEM images to quantify the size (length and diameter) of all the visible fibers separated and deposited on the sampling plate, as well as those partially separated from the main crystals. The results are summarized in Figure 2. As regards the length, about $99 \%$ of the total of the measured fibers lies in the range from $\sim 2$ to $\sim 30 \mu \mathrm{m}$ (average $17.7 \mu \mathrm{m}$ ), while the remaining $\sim 1 \%$ is longer than $30 \mu \mathrm{m}$. With over $65 \%$ of the measured fibers, the main mode corresponds to a fiber length between $\sim 15$ and $\sim 25 \mu \mathrm{m}$. Regarding diameter, the histogram shows the presence of a large population of fibers $(\sim 95 \%)$ characterized by a small diameter $(<1.5 \mu \mathrm{m}$; average of $0.6 \mu \mathrm{m})$, and the remainder $(\sim 5 \%)$ shows a small diameter (up to $2 \mu \mathrm{m}$ ). In particular, more than $30 \%$ of the measured fibers have a very small diameter, up to $0.3 \mu \mathrm{m}$, with a mean value of $0.25 \mu \mathrm{m}$.
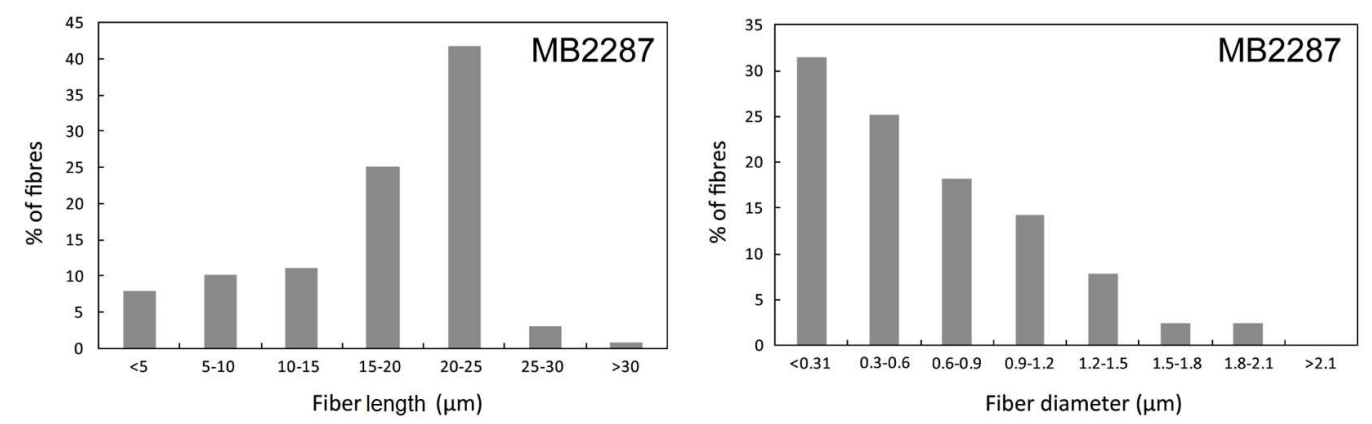

Figure 2. Size distribution of measured fibers (length and diameter) of the asbestiform MB2287 sample.

\subsection{Mineralogical Composition and Structural Data}

Owing to the difficulty of separate pure offretite crystals, XRPD data indicate that sample FF102 contains impurities of chabazite and calcite, whereas MB2287 has large amounts of chabazite and calcite and minor quartz plus additional clay minerals (Figure 3).

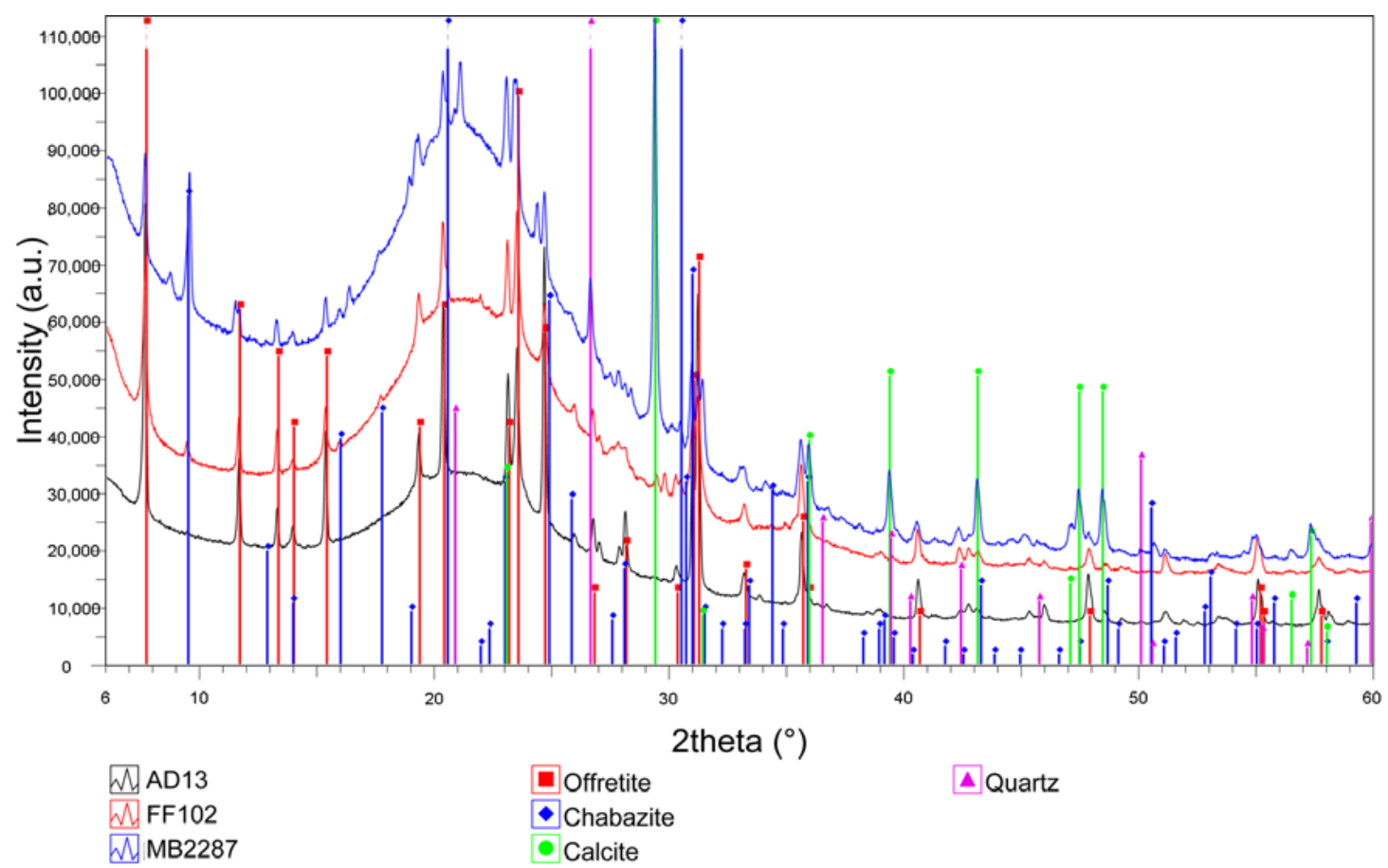

Figure 3. Diffraction patterns of the three offretite samples. Vertical bars refer to Bragg reflections of the various identified mineral. 
Refined cell parameters (Table 2) are similar among the samples and are consistent with those reported by [51]. Addition of the present data to the unit-cell volume vs. $\mathrm{R}(\mathrm{R}=\mathrm{Si} /(\mathrm{Si}+\mathrm{Al}))$ plot of [51] does not improve the poor correlation reported by those authors (Figure 4).

Table 2. Unit-cell parameters of studied offretite samples obtained by Rietveld refinements.

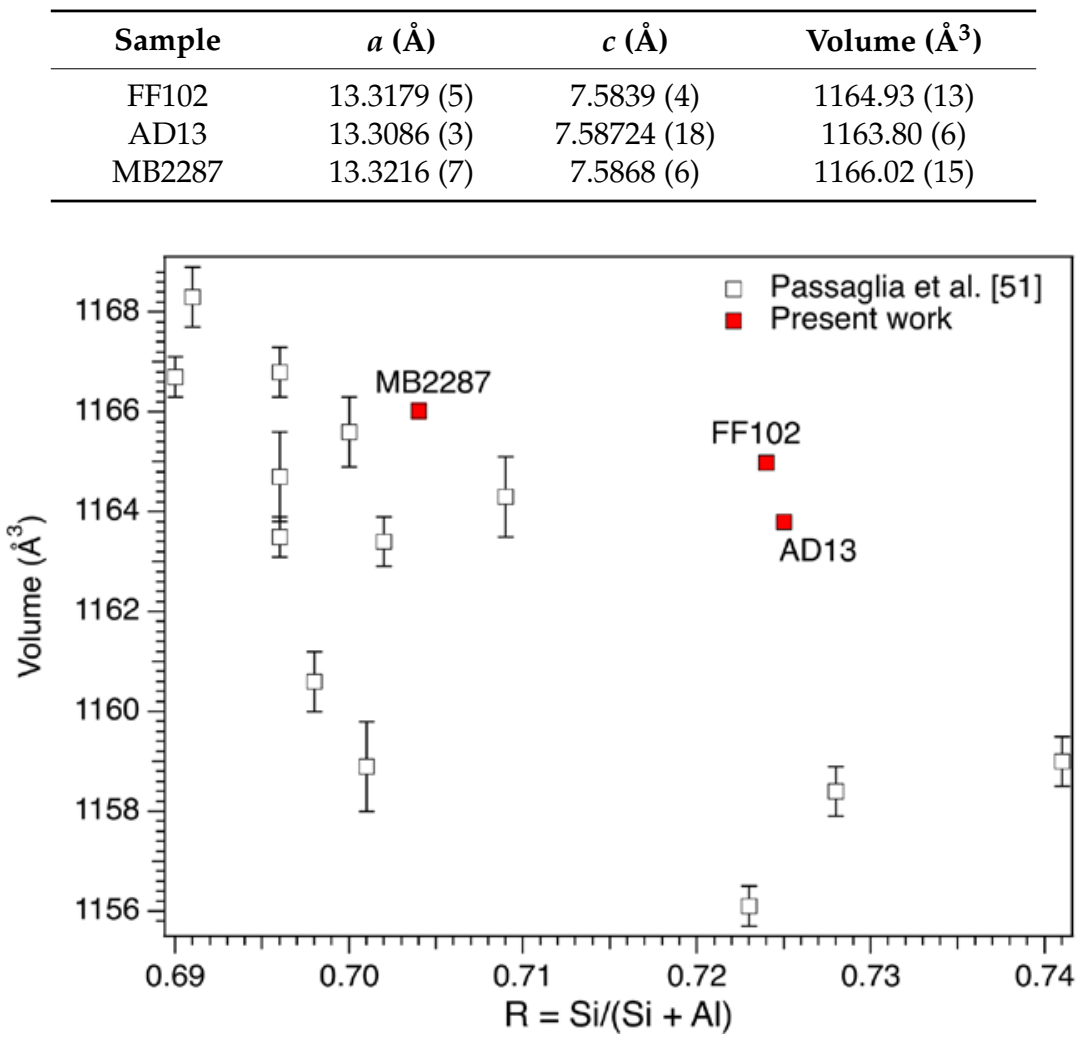

Figure 4. Correlation between unit-cell volume and $\mathrm{R}=\mathrm{Si} /(\mathrm{Si}+\mathrm{Al})$ of offretite samples. For comparison purpose, literature data from [51] are also reported.

Rietveld refinement of samples AD13 indicates a disordered $\mathrm{Si}$, Al distribution because of $\langle\mathrm{Si} 1-\mathrm{O}\rangle$ and $<\mathrm{Si} 2-\mathrm{O}>$ bond distances of 1.656 and $1.651 \AA$, respectively. According to Jones' determinative curves [73], the $\mathrm{Si}$, $\mathrm{Al}$ distribution at the tetrahedral sites is $\mathrm{Si} 1=\mathrm{Al}_{4.03} \mathrm{Si}_{7.97}$ and $\mathrm{Si} 2=\mathrm{Al}_{1.82} \mathrm{Si}_{4.18}$ corresponding to an $\mathrm{R}$ ratio of 0.675 . This value is slightly outside the reported range $0.69-0.74$ of offretite [51] and smaller than 0.724 obtained from chemical data (see below). The structure agrees with that reported by [68]. Differences are related to the minor displacement of the extraframework (EF) cations and $\mathrm{H}_{2} \mathrm{O}$ located within the gmelinite cages. As far as EF cations are referred to, the refined site scattering (s.s.) of $62.8(11) \mathrm{e}^{-}$is moderately higher than that obtained from SEM-EDS of $55.5 \mathrm{e}^{-}$. Similarly, the refined s.s. of the OW sites is consistent with the occurrence of 17.3(2) $\mathrm{H}_{2} \mathrm{O}$ per formula unit (pfu). This value is slightly higher than the grand mean of offretite samples of ca. $16.3 \mathrm{H}_{2} \mathrm{O}$ pfu reported by [51]. It is worth noting that detailed scrutiny of the difference plot of the Rietveld refinement indicates, despite the adopted anisotropic peak shape approach, some difficulty to properly fit the 011,021 and 211 reflections that could be possibly related to the occurrence of strain deriving from minor fibers curling (Figure 5). Therefore, we may speculate that the small structural deviations mentioned above may be due to this reason. 

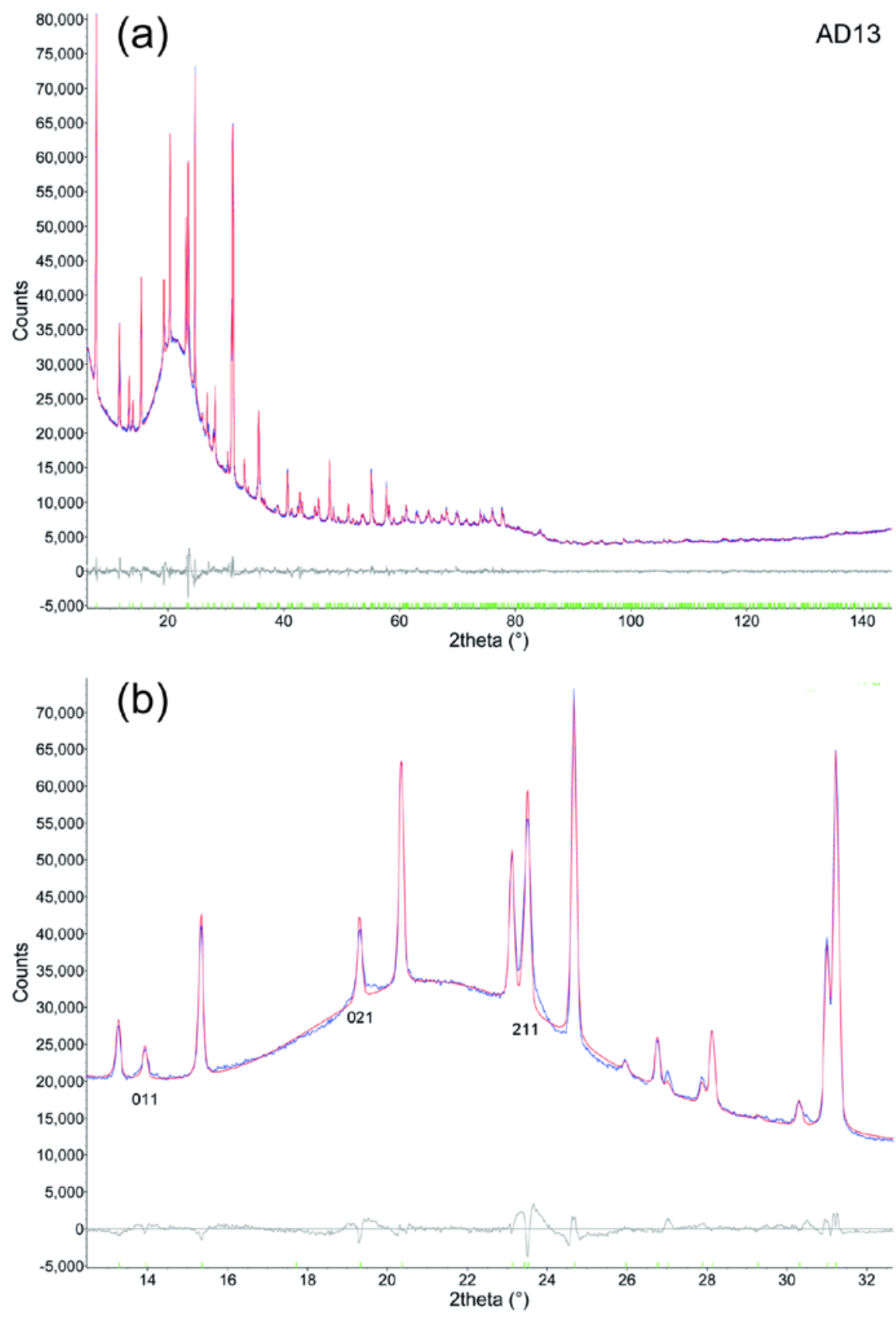

Figure 5. (a) Rietveld plots of sample AD13. Blue dotted line: experimental pattern; red continuous line: calculated; continuous grey line: difference plot; vertical green bars: position of the calculated Bragg reflections of offretite; (b) Magnified view of the Rietveld plots of sample AD13. Reflections 011, 021 and 211 show an imperfect fit of the tails that may be related to the occurrence of strain deriving from fibers curling.

\subsection{Chemical Data}

The point analyses acquired on the investigated samples are highly consistent, showing a variation of major elements within $2 \%-3 \%$, indicating a high degree of chemical homogeneity of each sample. The average chemical composition and relative standard deviations $(\sigma)$ are reported in Table 3 , whereas all the collected data are shown in Figure 6. 
Table 3. The chemical composition of the investigated offretite samples, showing the average values ( $\mathrm{N}$ is the number of point analysis) and standard deviation $(\sigma) . \Sigma \mathrm{T}$, is the sum of cations in tetrahedral sites; $\mathrm{E} \%$, measure of charge balance: $\mathrm{E} \%=100\left[\mathrm{Al}-\mathrm{Alk}_{\mathrm{th}}\right] / \mathrm{Alk}_{\mathrm{th}}$ where $\mathrm{Alk}_{\mathrm{th}}=\mathrm{Na}+\mathrm{K}+2(\mathrm{Ca}+\mathrm{Mg})$; $\mathrm{R}=\mathrm{Si} /(\mathrm{Si}+\mathrm{Al})$ ratio. Crystal chemical formula calculated on the basis of $18(\mathrm{Si}+\mathrm{Al})$ apfu. * Hypothesized $\mathrm{H}_{2} \mathrm{O}$ content of $19.34 \mathrm{wt} \%$.

\begin{tabular}{|c|c|c|c|c|c|c|}
\hline \multirow[b]{2}{*}{ Sample } & \multicolumn{2}{|c|}{ FF102 } & \multicolumn{2}{|c|}{ AD13 } & \multicolumn{2}{|c|}{ MB2287 } \\
\hline & $\begin{array}{c}\text { Average } \\
\mathbf{N}=7\end{array}$ & $\sigma$ & $\begin{array}{c}\text { Average } \\
\mathrm{N}=8\end{array}$ & $\sigma$ & $\begin{array}{c}\text { Average } \\
\mathbf{N}=7\end{array}$ & $\sigma$ \\
\hline $\mathrm{SiO}_{2}$ & 53.27 & 1.42 & 53.06 & 0.30 & 52.29 & 0.42 \\
\hline $\mathrm{Al}_{2} \mathrm{O}_{3}$ & 17.18 & 0.91 & 17.07 & 0.33 & 18.59 & 0.38 \\
\hline $\mathrm{MgO}$ & 2.04 & 0.11 & 2.65 & 0.25 & 2.98 & 0.20 \\
\hline $\mathrm{CaO}$ & 4.28 & 0.57 & 4.17 & 0.36 & 3.68 & 0.22 \\
\hline $\mathrm{Na}_{2} \mathrm{O}$ & - & - & - & - & - & - \\
\hline $\mathrm{K}_{2} \mathrm{O}$ & 3.89 & 0.21 & 3.70 & 0.41 & 3.12 & 0.20 \\
\hline $\mathrm{H}_{2} \mathrm{O}$ & 19.34 * & - & 19.34 * & - & 19.34 * & - \\
\hline Total & 80.66 & - & 80.66 & - & 80.66 & - \\
\hline $\mathrm{Si}$ & 13.04 & 0.29 & 13.05 & 0.09 & 12.68 & 0.10 \\
\hline $\mathrm{Al}$ & 4.96 & 0.29 & 4.95 & 0.09 & 5.32 & 0.10 \\
\hline$\Sigma \mathrm{T}$ & 18.00 & - & 18.00 & - & 18.00 & - \\
\hline $\mathrm{Mg}$ & 0.75 & 0.04 & 0.97 & 0.08 & 1.08 & 0.07 \\
\hline $\mathrm{Ca}$ & 1.13 & 0.15 & 1.10 & 0.13 & 0.96 & 0.06 \\
\hline $\mathrm{Na}$ & - & - & - & - & - & - \\
\hline $\mathrm{K}$ & 1.22 & 0.07 & 1.16 & 0.13 & 0.97 & 0.06 \\
\hline$\Sigma$ EFs.s. & 54.53 & - & 55.49 & - & 55.59 & - \\
\hline $\mathrm{O}$ & 36.00 & - & 36.18 & - & 35.86 & - \\
\hline $\mathrm{H}_{2} \mathrm{O}$ & 15.79 & 0.09 & 15.70 & 0.04 & 15.78 & 0.02 \\
\hline $\mathrm{R}$ & 0.72 & 0.02 & 0.72 & 0.01 & 0.70 & 0.01 \\
\hline $\mathrm{E} \%$ & -0.22 & 3.12 & -6.05 & 3.75 & 5.38 & 3.52 \\
\hline $\mathrm{Mg} /(\mathrm{Ca}+\mathrm{Na})$ & 0.68 & - & 0.89 & - & 1.13 & - \\
\hline
\end{tabular}

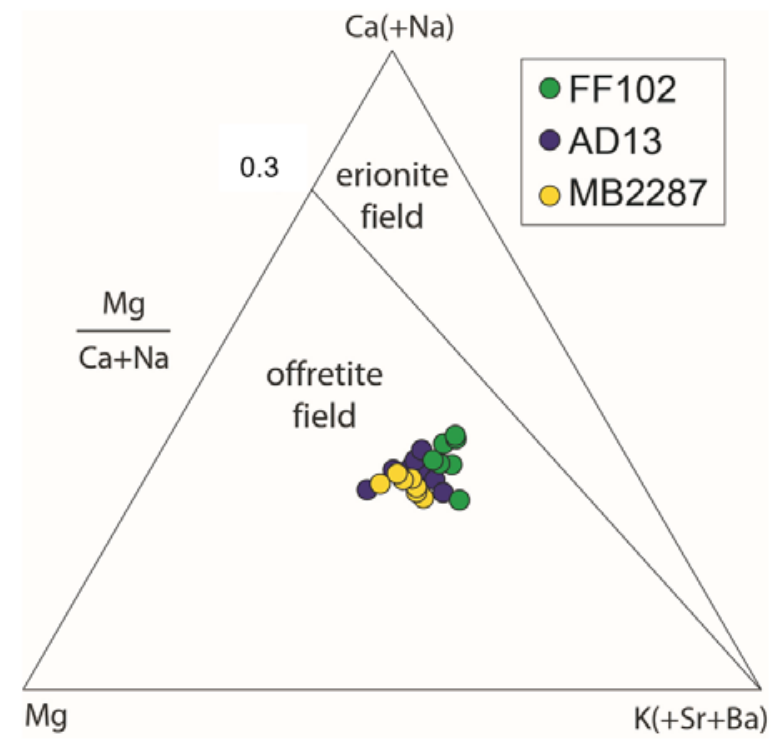

Figure 6. Ternary compositional plot [51] of the studied offretite samples, showing the distribution of extra-framework cations and the fields of erionite and offretite.

The average chemical composition of stocky-prismatic offretite of sample FF102 is $\left(\mathrm{K}_{1.22} \mathrm{Mg}_{0.75} \mathrm{Ca}_{1.13}\right) \cdot\left(\mathrm{Al}_{4.96} \mathrm{Si}_{13.04} \mathrm{O}_{36.00}\right) \cdot 15.79 \mathrm{H}_{2} \mathrm{O}$. The $\mathrm{R}$ ratio is in the range 0.71-0.74 (average 0.72), which is consistent with the interval $0.69-0.74$ identified by [51] for offretite. The $\mathrm{K}^{+}$and $\mathrm{Ca}^{2+}$ 
extra-framework (EF) cations are present in a comparable amount, being in the range 1.12-1.30 apfu and 1.73-2.56 apfu, respectively. The $\mathrm{Mg}^{2+}$ content ranges from 0.70 to 0.79 apfu and the $\mathrm{Mg} /(\mathrm{Ca}+\mathrm{Na})$ ratio, which is considered the most significant chemical parameter for the distinction between erionite and offretite [51], is in the range 0.54-0.88 (average 0.68).

The prismatic to acicular offretite $\mathrm{AD} 13$ has an average chemical formula $\left(\mathrm{K}_{1.16} \mathrm{Mg}_{0.97} \mathrm{Ca}_{1.10}\right) \cdot\left(\mathrm{Al}_{4.95} \mathrm{Si}_{13.05} \mathrm{O}_{36.18}\right) \cdot 15.70 \mathrm{H}_{2} \mathrm{O}$. The $\mathrm{R}$ ratio lies in the range 0.72-0.73, in agreement with literature data. The $\mathrm{K}^{+}$content $(0.91-1.37 \mathrm{apfu})$ is similar to that of $\mathrm{Ca}^{2+}(0.91-1.21 \mathrm{apfu})$, but with an average value slightly higher for $\mathrm{K}^{+}$. Moreover, the $\mathrm{Mg}^{2+}$ content is also high, ranging from 0.88 to $1.11 \mathrm{apfu}$, while the $\mathrm{Mg} /(\mathrm{Ca}+\mathrm{Na}$ ) ratio range from 0.73 to 1.22 (average 0.89 ).

The asbestiform offretite MB2287 has an average chemical formula $\left(\mathrm{K}_{0.97} \mathrm{Mg}_{1.08} \mathrm{Ca}_{0.96}\right)\left(\mathrm{Al}_{5.32} \mathrm{Si}_{12.68} \mathrm{O}_{35.86}\right) \cdot 15.78 \mathrm{H}_{2} \mathrm{O}$. The $\mathrm{R}$ ratio varies from 0.70 to 0.71 , an interval well within the range defined for offretite [51]. In this sample, all EF cations $\mathrm{K}^{+}, \mathrm{Ca}^{2+}$ and $\mathrm{Mg}^{2+}$ are present in comparable amounts. The $\mathrm{K}^{+}$content ranges from 0.91 to $1.06 \mathrm{apfu}$, while $\mathrm{Ca}^{2+}$ ranges from 0.89 to $1.05 \mathrm{apfu}$. The $\mathrm{Mg}^{2+}$ content is slightly higher than that of the previous samples, ranging from 0.96 to $1.20 \mathrm{apfu}$, and the $\mathrm{Mg} /(\mathrm{Ca}+\mathrm{Na}$ ) ratio is in the range 0.91-1.27 (average 1.13). It is interesting to notice that the analyzed samples show an inverse correlation between both $\mathrm{K}$ and $\mathrm{Mg}$ and $\mathrm{Ca}$ and $\mathrm{Mg}$ content. All chemical data plot within the offretite field in the ternary compositional plot (Figure 6).

\section{Discussion}

The main mechanisms by which an inhaled fibrous mineral particle induces pathological changes to comprise (a) physical features (diameter, length and aspect ratio); (b) chemical-mineralogical features (fibre type, chemical composition and surface reactivity); (c) the ability to generate reactive oxygen species (ROS); and (d) the biopersistence. These factors are also deeply interconnected: the fiber dimensions influence its surface reactivity, fiber structure and composition control its biopersistence, and biopersistence is associated with the fiber habit.

Concerning the physical features, the diameter seems to be the main factor controlling the ability of fibers to reach the lower respiratory tract, while macrophage phagocytosis is more dependent on fiber length $[7,74]$. According to [4], an elongated particle is defined as "inhalable" for humans when its diameter is $<3.5 \mu \mathrm{m}$, while [19] considers as inhalable the fibers with a diameter-length ratio $\geq 1: 3$, a length $>5 \mu \mathrm{m}$, and a diameter $<3 \mu \mathrm{m}$. Fibers $\leq 0.25 \mu \mathrm{m}$ in diameter and $>8 \mu \mathrm{m}$ in length seem to be the most carcinogenic [3], but the majority of fibers detected in the lung and mesothelial tissues are generally $<1 \mu \mathrm{m}$ in diameter and shorter than five $\mu \mathrm{m}$ in length $[5,75,76]$. Consequently, small-size fibers should not be excluded from those contributing to the induction of human MM, especially in high exposure environments. This is further supported by the fact that ultrafine fibers are particularly suitable for penetration from the proximal area to the peripheral part of the lung and migration from the lung to the pleura and the other sites within the human $[6,77,78]$. Therefore, it is difficult to exclude fibers of a particular dimension from those producing disease within the lung or extrapulmonary sites.

In the investigated samples, the habit of offretite varies from stocky-prismatic crystals with a solid appearance of FF102, through prismatic or acicular with the rigid mechanical behavior of AD13, to asbestiform crystals with rigid to the flexible behavior of MB2287. Offretite with prismatic and acicular crystal habits occurs more commonly, representing $\sim 84 \%$ of the total studied samples, while offretite with asbestiform habit is relatively rare and has been found in $\sim 16 \%$ of the total samples. However, it is relevant to highlight that asbestiform offretite had never been reported in northern Italy and this work represents its first finding and characterization. The stocky-prismatic and prismatic crystals have diameters of $\sim 50 \mu \mathrm{m}$ and lengths up to $500 \mu \mathrm{m}$, while the acicular variety is characterized by the same lengths but very small diameters $(<1 \mu \mathrm{m})$. The asbestiform crystals consist of fibers and fibrils with a diameter ranging from $<<1 \mu \mathrm{m}$ up to $4 \mu \mathrm{m}$, and a length which is in the range from $\sim 2$ to $\sim 30 \mu \mathrm{m}$ (average $\sim 18 \mu \mathrm{m})$. In particular, $\sim 95 \%$ of fibers are characterized by a small diameter $(<1.5 \mu \mathrm{m}$, average $0.6 \mu \mathrm{m})$, and more than $30 \%$ of the measured fibers have a very small diameter $(<0.3 \mu \mathrm{m}$, average $0.25 \mu \mathrm{m}$ ). According to [18] indications, all of these fibers may be considered as "inhalable," 
and they are well within the range of the "more carcinogenic fibers" regarding diameter [3]. The main mode observed in the offretite fibers of MB2287 is $20-25 \mu \mathrm{m}$, and $93 \%$ of the measured fibers are $>5 \mu \mathrm{m}$, and therefore they may also be significantly associated with carcinogenesis when breathed in term of lengths $[3,10,19]$. About the physical features, particular attention also needs to be paid to reliably evaluating the toxicological effects related not only to the dimension of offretite fibers, but also to their flexibility and their tendency to split, features that may significantly modify their surface area and, consequently, their reactivity [18,79]. The various offretite samples show different mechanical behavior, having an extremely fibrous with flexible to rigid appearance or forming prismatic to acicular, brittle crystals. In the mineral fibers, the flexibility might significantly transform the shape of the particles, leading to variations of both aerodynamic properties and physical particle deposition mechanisms [80,81].

The chemical-structural features of the mineral fibers are also of critical importance to evaluate the pathological changes, being related to their durability in the human body. Bearing in mind that the interactions between fibers and biological environment occur on the fiber surface, the surface chemical composition and specific surface area are the most important elements that need to be considered. The chemical composition of the investigated offretite samples is coherent with reference data: $\mathrm{R}$ ranges from 0.71 to 0.74 , the $\mathrm{EF}$ cations $\mathrm{K}^{+}, \mathrm{Mg}^{2+}$ and $\mathrm{Ca}^{2+}$ are present in all samples in comparable proportions, and $\mathrm{Na}^{+}, \mathrm{Sr}^{2+}, \mathrm{Ba}^{2+}$ and $\mathrm{Fe}$ are absent. All compositions plot within the offretite field in the ternary diagram of Figure 6. However, observing the chemical data in greater detail, it can be observed that the prismatic to acicular crystals have similar compositions, with $\mathrm{Mg}^{2+}$ content slightly lower than $\mathrm{K}^{+}$and $\mathrm{Ca}^{2+}$; differently, the fibrous offretite is characterized by a $\mathrm{Mg}^{2+}$ content which is slightly higher than that of the other EF cations. The crystal structure of sample AD13 shows small differences concerning that of prismatic offretite [68], possibly induced by minor curling of the fibers.

The present study indicates that, in different lithotypes of northern Italy, the zeolite offretite may crystallize with asbestiform habit, and therefore may be potentially harmful. This is even more concrete if one considers that many of these rocks are extensively quarried and widely employed for a variety of uses, most commonly as an aggregate. Crushed basalt is added to many construction jobs, including in asphalt paving, mixed with concrete, and as a rock filtering agent in many drain fields. Basalt is also used as the bedrock for railroad tracks, providing drainage and support. As a consequence, further than potential environmental exposure produced by natural weathering processes, occupational exposure during the phases of extraction and processing of offretite-containing rocks should also be taken into account, and additional environmental exposure due to the uses of such material also needs to be considered.

For the above reason, the related host-rocks should be carefully checked before their use as building or construction materials and, to this aim, the role of geoscientists is crucial in guiding safe rock extraction. The present results suggest the need for a detailed Italian mapping of natural sites characterized by the potential occurrence of fibrous minerals, with particular regard to the zeolites erionite and offretite. Furthermore, these data can be used to assess the health risks related to the exposure to mineral fibers during human activities, such as road constructions, quarry excavations and farming that may induce disturbance in the mineral fibers-bearing rocks and trigger unplanned fibers release process.

It is relevant to note that, among the fibrous zeolites, erionite is the only one that was classified as a human carcinogen [38], although other species should not be considered intrinsically safe [82,83]. Despite the lack of epidemiological information on populations exposed to natural asbestiform minerals other than asbestos and erionite, we suggest that all mineral fibers of similar size, habit, and biopersistence may carry a risk for human health.

Finally, we believe the results obtained in this research could be used: (i) to identify potentially hazardous health areas in view of the presence of zeolite minerals fibres; (ii) to provide data for the compulsory Italian mapping of natural sites that are characterized by the presence of the fibrous 
zeolites; and (iii) to map fibrous minerals (e.g., offretite and erionite) that are classified as non-asbestos and, therefore, not regulated by law but that could be just as hazardous to human health.

Supplementary Materials: The following are available online at http://www.mdpi.com/2075-163x/8/2/69/s1, Table S1: .cif data.

Acknowledgments: This research was made possible by a research grant from DiSPEA (award number RisIntMM2017) awarded to M.M. The authors would like to thank Franco Filippi and Dino Agnoli for kindly providing the FF102 and AD13 samples, respectively.

Author Contributions: M.M. and M.G. conceived the research, analysed the results, wrote and revised the manuscript; P.A. and M.B. analyzed the data and revised the manuscript; L.V. performed SEM-EDS analysis and revised the manuscript; A.P. and P.B. conducted XRPD experiments, performed structure refinements, analysed the results, wrote and revised the manuscript.

Conflicts of Interest: The authors declare no conflict of interest.

\section{References}

1. Andujar, P.; Lacourt, A.; Brochard, P.; Pairon, J.-C.; Jaurand, M.-C.; Jean, D. Five years update on relationships between malignant pleural mesothelioma and exposure to asbestos and other elongated mineral particles. J. Toxicol. Environ. Health B 2016, 19, 151-172. [CrossRef] [PubMed]

2. Gualtieri, A.F. Mineral Fibres: Crystal Chemistry, Chemical-Physical Properties, Biological Interaction and Toxicity; EMU Notes in Mineralogy; European Mineralogical Union and the Mineralogical Society of Great Britain and Ireland: London, UK, 2017; Volume 18.

3. Stanton, M.F.; Layard, M.; Tegeris, A.; Miller, E.; May, M.; Morgan, E.; Smith, A. Relation of particles dimension to carcinogenicity in amphibole asbestoses and other fibrous minerals. J. Nat. Cancer Inst. 1981, 67, 965-975. [PubMed]

4. Lee, K.P. Lung response to particulates with emphasis on asbestos and other fibrous dust. Crit. Rev. Toxicol. 1985, 14, 33-86. [CrossRef] [PubMed]

5. Aust, A.E.; Cook, P.M.; Dodson, R.D. Morphological and chemical mechanisms of elongated mineral particle toxicities. J. Toxicol. Environ. Health B 2011, 14, 40-75. [CrossRef] [PubMed]

6. Boulanger, G.; Andujar, P.; Pairon, J.C.; Billon-Galland, M.A.; Dion, C.; Dumortier, P.; Brochard, P.; Sobaszek, A.; Bartsch, P.; Paris, C.; et al. Quantification of short and long asbestos fibers to assess asbestos exposure: A review of fiber size toxicity. Environ. Health 2014, 13, 59. [CrossRef] [PubMed]

7. Belluso, E.; Cavallo, A.; Halterman, D. Crystal habit of mineral fibres. In Mineral Fibres: Crystal Chemistry, Chemical-Physical Properties, Biological Interaction and Toxicity; EMU Notes in Mineralogy; Gualtieri, A.F., Ed.; European Mineralogical Union and the Mineralogical Society of Great Britain and Ireland: London, UK, 2017; Volume 18, pp. 65-110.

8. Hesterberg, T.W.; Chase, G.; Axten, C.; Miller, W.C.; Musselman, R.P.; Kamstrup, O.; Hadley, J.; Morscheidt, C.; Bernstein, D.M.; Thevenaz, P. Biopersistence of synthetic vitreous fibers and amosite asbestos in the rat lung following inhalation. Toxicol. Appl. Pharmacol. 1998, 151, 262-275. [CrossRef] [PubMed]

9. Maxim, D.L.; Hadley, J.G.; Potter, R.M.; Niebo, R. The role of fiber durability/biopersistence of silica-based synthetic vitreous fibers and their influence on toxicology. Regul. Toxicol. Pharmacol. 2006, 46, 42-62. [CrossRef] [PubMed]

10. Bernstein, D.M.; Chevalier, J.; Smith, P. Comparison of Calidria chrysotile asbestos to pure tremolite: Final results of the inhalation biopersistence and histopathology examination following short-term exposure. Inhal. Toxicol. 2005, 17, 427-449. [CrossRef] [PubMed]

11. Muhle, H.; Bellmann, B.; Pott, F. Durability of various mineral fibres in rat lungs, mechanisms in fibre carcinogenesis. In NATO ASI Series A: Life Sciences; Brown, R.C., Hoskins, J.A., Johnson, N.F., Eds.; Plenum Press: New York, NY, USA, 1991; Volume 223, pp. 181-187.

12. Ballirano, P.; Pacella, A.; Cremisini, C.; Nardi, E.; Fantauzzi, M.; Atzei, D.; Rossi, A.; Cametti, G. Fe (II) segregation at a specific crystallographic site of fibrous erionite: A first step toward the understanding of the mechanisms inducing its carcinogenicity. Microporous Mesoporous Mater. 2015, 211, 49-63. [CrossRef]

13. Crovella, S.; Bianco, A.M.; Vuch, J.; Zupin, L.; Moura, R.R.; Trevisan, E.; Schneider, M.; Brollo, A.; Nicastro, E.M.; Cosenzi, A.; et al. Iron signature in asbestos-induced malignant pleural mesothelioma: A population-based autopsy study. J. Toxicol. Environ. Health A 2016, 79, 129-141. [CrossRef] [PubMed] 
14. Pacella, A.; Fantauzzi, M.; Atzei, D.; Cremisini, C.; Nardi, E.; Montereali, M.R.; Rossi, A.; Ballirano, P. Iron within the erionite cavity and its potential role in inducing its toxicity: Evidences of Fe (III) segregation as extra-framework cation. Microporous Mesoporous Mater. 2017, 237, 168-179. [CrossRef]

15. Hochella, M.F. Surface chemistry, structure, and reactivity of hazardous mineral dust. In Health Effects of Mineral Dusts; Reviews in Mineralogy and Geochemistry; Guthrie, G.D., Mossman, B.T., Eds.; Bookcrafters: Chelsea, MI, USA, 1993; Volume 28, pp. 275-308.

16. Bloise, A.; Barca, D.; Gualtieri, A.F.; Pollastri, S.; Belluso, E. Trace elements in hazardous mineral fibres. Environ. Pollut. 2016, 216, 314-323. [CrossRef] [PubMed]

17. Pollastri, S.; Gualtieri, A.F.; Gualtieri, M.L.; Hanuskova, M.; Cavallo, A.; Gaudino, G. The Zeta potential of mineral fibres. J. Hazard. Mater. 2014, 276, 469-479. [CrossRef] [PubMed]

18. Mattioli, M.; Giordani, M.; Dogan, M.; Cangiotti, M.; Avella, G.; Giorgi, R.; Dogan, A.U.; Ottaviani, M.F. Morpho-chemical characterization and surface properties of carcinogenic zeolite fibers. J. Hazard. Mater. 2016, 306, 140-148. [CrossRef] [PubMed]

19. World Health Organization (WHO). Asbestos and other Natural Mineral Fibers; Environmental Health Criteria: Geneva, Switzerland, 1986; Volume 53, pp. 69-107.

20. National Institute for Occupational Safety and Health (NIOSH). Asbestos Fibers and Other Elongate Mineral Particles: State of the Science and Roadmap for Research; Current Intelligence Bulletin 62, Version 4; Department of Health and Human Services: Cincinnati, OH, USA, 2011.

21. Gianfagna, A.; Ballirano, P.; Bellatreccia, F.; Bruni, B.; Paoletti, L.; Oberti, R. Characterisation of amphibole fibres linked to mesothelioma in the area of Biancavilla, eastern Sicily, Italy. Mineral. Mag. 2003, 67, 1221-1229. [CrossRef]

22. Andreozzi, G.B.; Ballirano, P.; Gianfagna, A.; Mazziotti-Tagliani, S.; Pacella, A. Structural and spectroscopic characterization of a suite of fibrous amphiboles with high environmental and health relevance from Biancavilla (Sicily, Italy). Am. Mineral. 2009, 94, 1333-1340. [CrossRef]

23. Gazzano, E.; Riganti, C.; Tomatis, M.; Turci, F.; Bosia, A.; Fubini, B.; Ghigo, D. Potential toxicity of nonregulated asbestiform minerals: Balangeroite from the Western Alps. Part 3: Depletion of antioxidant defenses. J. Toxicol. Environ. Health A 2005, 68, 41-49. [CrossRef] [PubMed]

24. Groppo, C.; Tomatis, M.; Turci, F.; Gazzano, E.; Ghigo, D.; Compagnoni, R.; Fubini, B. Potential Toxicity of Nonregulated Asbestiform Minerals: Balangeroite From the Western Alps. Part 1: Identification and Characterization. J. Toxicol. Environ. Health A 2005, 68, 1-19. [CrossRef] [PubMed]

25. Price, B. Industrial-grade talc exposure and the risk of mesothelioma. Crit. Rev. Toxicol. 2010, 40, 513-530. [CrossRef] [PubMed]

26. García Romero, E.; Suarez, M. Sepiolite-palygorskite: Textural study and genetic considerations. Appl. Clay Sci. 2013, 86, 129-144. [CrossRef]

27. Mattioli, M.; Giardini, L.; Roselli, C.; Desideri, D. Mineralogical characterization of commercial clays used in cosmetics and possible risk for health. Appl. Clay Sci. 2016, 119, 449-454. [CrossRef]

28. Larson, D.; Powers, A.; Ambrosi, J.-P.; Tanjia, M.; Napolitano, A.; Flores, E.G.; Baumann, F.; Pellegrini, L.; Jennings, C.J.; Buck, B.J.; et al. Investigating palygorskite's role in the development of mesothelioma in southern Nevada: Insights into fiber-induced carcinogenicity. J. Toxicol. Environ. Health B 2016, 19, $213-230$. [CrossRef] [PubMed]

29. Ballirano, P.; Bloise, A.; Gualtieri, A.F.; Lezzerini, M.; Pacella, A.; Perchiazzi, N.; Dogan, M.; Dogan, A.U. The crystal structure of mineral fibres. In Mineral Fibres: Crystal Chemistry, Chemical-Physical Properties, Biological Interaction and Toxicity; Gualtieri, A.F., Ed.; EMU Notes in Mineralogy; European Mineralogical Union and the Mineralogical Society of Great Britain and Ireland: London, UK, 2017; Volume 18, pp. 17-64.

30. Baris, I.; Artvinli, M.; Saracci, R.; Simonato, L.; Pooley, F.; Skidmore, J.; Wagner, C. Epidemiological and environmental evidence of the health effects of exposure to erionite fibres: A four-year study in the Cappadocian region of Turkey. Int. J. Cancer 1987, 39, 10-17. [CrossRef] [PubMed]

31. Carbone, M.; Emri, S.; Dogan, A.U.; Steele, I.; Tuncer, M.; Pass, H.I.; Baris, Y.I. A mesothelioma epidemic in Cappadocia: Scientific developments and unexpected social outcomes. Nat. Rev. Cancer 2007, 7, 147-154. [CrossRef] [PubMed]

32. Demirer, E.; Ghattas, C.F.; Radwan, M.O.; Elamin, E.M. Clinical and prognostic features of erionite-induced malignant mesothelioma. Yonsei Med. J. 2015, 56, 311-323. [CrossRef] [PubMed] 
33. Coffin, D.L.; Cook, P.M.; Creason, J.P. Relative mesothelioma induction in rats by mineral fibers: Comparison with residual pulmonary mineral fiber number and epidemiology. Inhal. Toxicol. 1992, 4, 273-300. [CrossRef]

34. Bertino, P.; Marconi, A.; Palumbo, L.; Bruni, B.M.; Barbone, D.; Germano, S.; Dogan, A.U.; Tassi, G.F.; Porta, C.; Mutti, L.; Gaudino, G. Erionite and asbestos differently cause transformation of human mesothelial cells. Int. J. Cancer 2007, 121, 2766-2774. [CrossRef] [PubMed]

35. Hillegass, J.M.; Miller, J.M.; MacPherson, M.B.; Westbom, C.M.; Sayan, M.; Thompson, J.K.; Macura, S.L.; Perkins, T.N.; Beuschel, S.L.; Alexeeva, V.; et al. Asbestos and erionite prime and activate the NLRP3 inflammasome that stimulates autocrine cytokine release in human mesothelial cells. Part. Fibre Toxicol. 2013, 10, 39. [CrossRef] [PubMed]

36. De Assis, L.V.M.; Locatelli, J.; Isoldi, M.C. The role of key genes and pathways involved in the tumorigenesis of malignant mesothelioma. Biochim. Biophys. Acta 2014, 1845, 232-247. [CrossRef] [PubMed]

37. Zebedeo, C.N.; Davis, C.; Pena, C.; Ng, K.W.; Pfau, J.C. Erionite induces production of autoantibodies and IL-17 in C57BL/ 6 mice. Toxicol. Appl. Pharmacol. 2014, 275, 257-264. [CrossRef] [PubMed]

38. International Agency for Research on Cancer (IARC). IARC Monographs on the Evaluation of the Carcinogenic Risk to Humans; Overall Eval. Carcinog. Updating IARC Monographs Vol. 1 to 42; IARC: Lyon, France, 1987; Supplement 7; p. 150.

39. International Agency for Research on Cancer (IARC). IARC Monographs on the evaluation of the carcinogenic risk to humans. Arsen. Met. Fibres Dusts 2011, 100, 311-316.

40. Van Gosen, B.S.; Blitz, T.A.; Plumlee, G.S.; Meeker, G.P.; Pierson, M.P. Geologic occurrences of erionite in the United States: An emerging national public health concern for respiratory disease. Environ. Geochem. Health 2013, 35, 419-430. [CrossRef] [PubMed]

41. Saini-Eidukat, B.; Triplet, J.W. Erionite and offretite from the Killdeer Mountains, Dunn County, North Dakota, USA. Am. Mineral. 2014, 99, 8-15. [CrossRef]

42. Baumann, F.; Carbone, M. Environmental risk of mesothelioma in the United States: An emerging concern-epidemiological issues. J. Toxicol. Environ. Health B 2016, 19, 231-249. [CrossRef] [PubMed]

43. Ortega-Guerrero, M.A.; Carrasco-Núñez, G. Environmental occurrence, origin, physical and geochemical properties, and carcinogenic potential of erionite near San Miguel de Allende, Mexico. Environ. Geochem. Health 2014, 36, 517-529. [CrossRef] [PubMed]

44. Ortega-Guerrero, M.A.; Carrasco-Núñez, G.; Barragán-Campos, H.; Ortega, M.R. High incidence of lung cancer and malignant mesothelioma linked to erionite fibre exposure in a rural community in Central Mexico. Occup. Environ. Med. 2015, 72, 216-218. [CrossRef] [PubMed]

45. Ilgren, E.B.; Kazemian, H.; Hoskins, J.A. Kandovan the next 'Capadoccia'? A potential public health issue for erionite related mesothelioma risk. Epidemiol. Biostat. Public Health 2015, 12, 1-12. [CrossRef]

46. Giordani, M.; Mattioli, M.; Dogan, M.; Dogan, A.U. Potential carcinogenic erionite from Lessini Mounts, NE Italy: Morphological, mineralogical and chemical characterization. J. Toxicol. Environ. Health A 2016, 79, 808-824. [CrossRef] [PubMed]

47. Giordani, M.; Mattioli, M.; Ballirano, P.; Pacella, P.; Cenni, M.; Boscardin, M.; Valentini, L. Geological occurrence, mineralogical characterization and risk assessment of potentially carcinogenic erionite in Italy. J. Toxicol. Environ. Health B 2017, 20, 81-103. [CrossRef] [PubMed]

48. Cangiotti, M.; Battistelli, M.; Salucci, S.; Falcieri, E.; Mattioli, M.; Giordani, M.; Ottaviani, M.F. Electron paramagnetic resonance and transmission electron microscopy study of the interactions between asbestiform zeolite fibers and model membranes. J. Toxicol. Environ. Health A 2017, 80, 171-187. [CrossRef] [PubMed]

49. Cangiotti, M.; Salucci, S.; Battistelli, M.; Falcieri, E.; Mattioli, M.; Giordani, M.; Ottaviani, M.F. EPR, TEM and cell viability study of asbestiform zeolite fibers in cell media. Colloids Surf. B Biointerfaces 2018, 161, 147-155. [CrossRef] [PubMed]

50. Gottardi, G.; Galli, E. Natural Zeolites; Springer: Heidelberg, Germany, 1985.

51. Passaglia, E.; Artioli, G.; Gualtieri, A. Crystal chemistry of the zeolites erionite and offretite. Am. Mineral. 1998, 83, 577-589. [CrossRef]

52. Bish, D.L.; Ming, D.W. Natural Zeolites: Occurrence, Properties, Applications; Reviews in Mineralogy and Geochemistry 45; Mineralogical Society of America: Washington, DC, USA, 2001.

53. Passaglia, E.; Tagliavini, A. Chabazite-offretite epitaxial overgrowths in cornubianite from Passo Forcel Rosso, Adamello, Italy. Eur. J. Mineral. 1994, 6, 379-405. [CrossRef] 
54. Gard, J.A.; Tait, J.M. The crystal structure of the zeolite offretite $\mathrm{K}_{1.1} \mathrm{Ca}_{1.1} \mathrm{Mg}_{0.7}\left(\mathrm{Si}_{12.8} \mathrm{Al}_{5.2} \mathrm{O}_{36}\right)_{3} 15.2 \mathrm{H}_{2} \mathrm{O}$. Acta Crystallogr. B 1972, 28, 825-834. [CrossRef]

55. Guastoni, A.; Dugnani, M.; Pezzotta, F.; Bardelli, G. Offretite del lago d'Arno in alta Val Saviore, Parco dell'Adamello (Bs). Atti Soc. It. Sci. Nat. Museo Civ. St. Nat. Mil. 2002, 143, 195-207.

56. Mattioli, M.; Cenni, M.; Passaglia, E. Secondary mineral assemblages as indicators of multi stage alteration processes in basaltic lava flows: Evidence from the Lessini Mountains, Veneto Volcanic Province, Northern Italy. Per. Mineral. 2016, 85, 1-24.

57. Boscardin, M.; Checchi, A.; Filippi, F.; Guglielmino, S.; Pegoraro, S.; Pretto, G.; Zattra, A. Offretite del Veneto. Riv. Mineral. It. 1998, 22, 25-29.

58. Daleffe, A.; Boscardin, M. Offretite di Passo Roccolo tra Chiampo e S. Giovanni Ilarione (Lessini Orientali). Stud. Ric. Ass. Amici Mus. Civ. 2005, 12, 57-59.

59. Passaglia, E.; Tagliavini, A.; Gutoni, R. Offretite and other zeolites from Fittà (Verona, Italy). Neues Jahrb. Mineral. Monatshefte 1996, 418-428.

60. De Vecchi, G.P.; Sedea, R. The Paleogene basalt of the Veneto region (NE Italy). Mem. Inst. Geol. Mineral. Univ. Padua 1995, 47, 253-274.

61. Bonadiman, C.; Coltorti, M.; Milani, L.; Salvini, L.; Siena, F.; Tassinari, R. Metasomatism in the lithospheric mantle and its relationships to magmatism in the Veneto Volcanic Province, Italy. Per. Mineral. 2001, 70, 333-357.

62. Goldstein, J.I.; Newbury, D.E.; Echlin, P.; Joy, D.C.; Roming, A.D.; Lyman, C.E.; Fiori, C.; Lifshin, E. Scanning Electron Microscopy and X-ray Microanalysis, 2nd ed.; Plenum Press: New York, NY, USA, 1992.

63. Pacella, A.; Ballirano, P.; Cametti, G. Quantitative chemical analysis of erionite fibres using a micro-analytical SEM-EDX method. Eur. J. Mineral. 2016, 28, 257-264. [CrossRef]

64. Passaglia, E. The crystal chemistry of chabazites. Am. Mineral. 1970, 55, 1278-1301.

65. Dogan, A.U.; Dogan, M. Re-evaluation and re-classification of erionite series minerals. Environ. Geochem. Health 2008, 30, 355-366. [CrossRef] [PubMed]

66. Cametti, G.; Pacella, A.; Mura, F.; Rossi, M.; Ballirano, P. New morphological, chemical, and structural data of woolly erionite-Na from Durkee, Oregon, USA. Am. Mineral. 2013, 98, 2155-2163. [CrossRef]

67. Bruker AXS. Topas V.4.2: General Profile and Structure Analysis Software for Powder Diffraction Data; Bruker AXS: Karlsruhe, Germany, 2009.

68. Alberti, A.; Cruciani, G.; Galli, E.; Vezzalini, G. A re-examination of the crystal structure of the zeolite offretite. Zeolites 1996, 17, 457-461. [CrossRef]

69. Ballirano, P.; Andreozzi, G.B.; Dogan, M.; Dogan, A.U. Crystal structure and iron topochemistry of erionite-K from Rome, Oregon, USA. Am. Mineral. 2009, 94, 1262-1270. [CrossRef]

70. Sabine, T.M.; Hunter, B.A.; Sabine, W.R.; Ball, C.J. Analytical expressions for the transmission factor and peak shift in absorbing cylindrical specimens. J. Appl. Crystallogr. 1998, 31, 47-51. [CrossRef]

71. Ballirano, P. Effects of the choice of different ionisation level for scattering curves and correction for small preferred orientation in Rietveld refinement: The $\mathrm{MgAl}_{2} \mathrm{O}_{4}$ test case. J. Appl. Crystallogr. 2003, 36, 1056-1061. [CrossRef]

72. Katerinopoulou, A.; Balic-Zunic, T.; Lundegaard, L.F. Application of the ellipsoid modeling of the average shape of nanosized crystallites in powder diffraction. J. Appl. Crystallogr. 2012, 45, 22-27. [CrossRef]

73. Jones, J.B. Al-O and Si-O tetrahedral distances in aluminosilicate framework structures. Acta Crystallogr. B 1968, 24, 355-358. [CrossRef]

74. Oberdorster, G.; Castranova, V.; Asgharian, B.; Sayre, P. Inhalation exposure to carbon nanotubes (CNT) and carbon nanofibers (CNF): Methodology and dosimetry. J. Toxicol. Environ. Health B 2015, 18, 121-212. [CrossRef] [PubMed]

75. Dodson, R.F.; Atkinson, M.A.L.; Levin, J.L. Asbestos fiber length as related to potential pathogenicity: A critical review. Am. J. Ind. Med. 2003, 44, 291-297. [CrossRef] [PubMed]

76. Suzuki, Y.; Yuen, S.R.; Ashley, R. Short, thin asbestos fibers contribute to the development of human malignant mesothelioma: Pathological evidence. Int. J. Hyg. Environ. Health 2005, 208, 201-210. [CrossRef] [PubMed]

77. Gatti, A.; Rivasi, F. Biocompatibility of micro- and nano-particles. Part I: In liver and kidney. Biomaterials 2002, 23, 2381-2387. [CrossRef] 
78. Bunderson-Schelvan, M.; Pfau, J.C.; Crouch, R.; Holian, A. Non-pulmonary outcomes of asbestos exposure. J. Toxicol. Environ. Health B 2011, 14, 122-152. [CrossRef] [PubMed]

79. Matassa, R.; Familiari, G.; Relucenti, M.; Battaglione, E.; Downing, C.; Pacella, A.; Cametti, G.; Ballirano, P. A Deep Look Into Erionite Fibres: An Electron Microscopy Investigation of their Self-Assembly. Sci. Rep. 2015, 5, 16757. [CrossRef] [PubMed]

80. Donaldson, K.; Murphy, F.A.; Duffin, R.; Poland, C.A. Asbestos, carbon nanotubes and the pleural mesothelium: A review of the hypothesis regarding the role of long fibre retention in the parietal pleura, inflammation and mesothelioma. Part. Fibre Toxicol. 2010, 7, 5. [CrossRef] [PubMed]

81. Hofmann, W. Modelling inhaled particle deposition in the human lung-A review. J. Aerosol Sci. 2011, 42, 693-724. [CrossRef]

82. International Agency for Research on Cancer (IARC). IARC Monographs on the evaluation of the carcinogenic risk of chemicals to humans. Silica Some Silic. 1997, 42, 225-239.

83. Stephenson, D.J.; Fairchild, C.I.; Buchan, R.M.; Dakins, M.E. A fiber characterization of the natural zeolite, mordenite: A potential inhalation health hazard. Aerosol Sci. Technol. 1999, 30, 467-476. [CrossRef]

(C) 2018 by the authors. Licensee MDPI, Basel, Switzerland. This article is an open access article distributed under the terms and conditions of the Creative Commons Attribution (CC BY) license (http://creativecommons.org/licenses/by/4.0/). 